\title{
PENGGUNAAN MEDIA ELEKTRONIKA DALAM MENENTUKAN PELAKSANAAN WAKTU IBADAH MENURUT HUKUM ISLAM
}

\author{
Abdul Hafizh \\ Program Studi Ahwal syakhshiyah STAI Balaiselasa Pesisir Selatan \\ Jl. Air Batu No. 09, Balaiselasa, Ranah Pesisir, Pesisir Selatan, SUMBAR \\ aphiedmz@gmail.com
}

\begin{abstract}
Abstrak: Adanya keanekaragaman terhadap persoalan hisab dan rukyat ketika menentukan pelaksanaan waktu ibadah. Di mana keanekaragaman itu memicu beragamnya metode dan cara yang ditempuh, turut mengakibatkan beragamnya hasil yang diperoleh. Metode dan cara tersebut tidak lain dapat diklasifikasikan sebagai berikut ; 1) Manual dan, 2) Modern (serba cepat dan praktis dengan bantuan media elektronika). Mengingat sains semakin berkembang dan meningkat, mengakibatkan perkembangan Ilmu Falak terus menuju kesempurnaan. Maka secara otomatis mengalami perkembangan rumus atau metode dan cara. Oleh karena itu bisa saja terjadi rumus-rumus lama tidak berlaku lagi (batal). Namun di samping itu, ada juga para ulama, kiyai yang berperan dalam menentukan waktu ibadah tetap berpegang teguh memkai metode-metode lama yang sifatnya manual. Sebab sebagai salah satu alasannya menimbang Nabi Muhammad shallallahu 'alaihi wa sallam hanya mengerjakan seperti demikian. Pada hal tehnik hisab dan rukyat itu merupakan persoalan mu'amalah (mengangkut terhadap perbuatan manusia), bukan masalah ibadah yang hanya menunggu ketetapan dari Nabi Muhammad shallallahu 'alaihi wa sallam. Dengan timbulnya kesenjangan ini dalam hisab dan rukyat, maka penulis tertarik untuk mengkajinya lebih lanjut, agar masyarakat puas dan tidak lagi ribut serta membingungkan. Bentuk penelitian ini bersifat penelitian kepustakaan (Library Risearch). Data yang terkumpul diolah dengan menggunakan metode deduktif, induktif dan, analitik. Setelah melakukan penelitian penulis berkesimpulan bahwa media elektronika dapat menjawab persoalan waktu ibadah secara cepat, tepat dan akurat. Oleh karena itu perkembangan teknologi ini dapat mengubah tehnik hisab dan rukyat sepanjang tidak keluar dari prinsip Syari'at. Selanjutnya persoalan tehnik hisab dan rukyat dapat saja berkembang menurut arus perkembangan sains dan teknologi. Jadi penggunaan media elektronika dalam menentukan pelaksanaan waktu ibadah adalah sah dan boleh.
\end{abstract}

Kata Kunci: Hisab, Rukyat, Media Elektronika

\section{Pendahuluan}

Islam mempunyai kaitan yang rapat dengan falak dalam beberapa segi, terlihat dari peranannya dalam ibadah shalat sebagai penentu awal waktu shalat dan arah kiblat, dan ibadah puasa sebagai penentu awal bulan Ramadhan. Orang Islam perlu mengetahui waktu shalat dan arah kiblat ketika hendak melakukan shalat dengan panduan berdasarkan peredaran matahari yaitu matahari terbit, lalu 
melintasi meridian (berkulminasi atas) kemudian matahari terbenam. Sedangkan untuk mengetahui awal puasa berdasarkan peredaran bulan dalam mengelilingi bumi.

Suatu hal yang diyakini shalat dan puasa adalah perintah syar'i kepada muslim mukallaf. Suatu kewajiban 'aini untuk melakukannya. Tentu dalam merealisasikan perintah-Nya tidak terlepas dari waktu-waktu kapan wajibnya dari masing-masing ibadah tersebut. Semua hal tersebut tertuang dalam firman Allah ta'ala dan hadits Nabi shallallahu 'alaihi wa sallam.

Untuk mengetahui awal waktu shalat, awal puasa (awal bulan qamariah) dan menghadap kiblat adalah dengan ilmu pengetahuan, yakni ilmu falak. Dengan demikian menjadi suatu kewajiban syar'i untuk mempelajarinya.

Memang tanpa disadari, sains dan teknologi berkembang terus menurut perkembangan zamannya. Dalam prakteknya melihat hilal masa Nabi Muhammad shallallahu 'alaihi wa sallam dan Umar bin Khattab dengan rukyat bil 'aini. Sebab sains ketika itu mengandung paham geosentris bumi sebagai pusat tata surya. Artinya matahari mengelilingi bumi- yang dikemukakan oleh Ptolemeus. Sedangkan dewasa ini sebaliknya, merukyat dilakukan dengan alat bantu serta paham geosentris itu ditumbangkan oleh Galileo Galilie dengan mengembangkan paham heliosentris -matahari sebagai pusat tata surya. Artinya bumi mengelilingi matahari- oleh Copernicus $1473 \mathrm{M}$.

Selanjutnya dalam perhitungan (hisab), karena banyaknya cara melakukan hisab tentu beragam pula rumus yang dipakai. Contoh :

- Hisab 'urfi merupakan hisab yang digunakan untuk melakukan penanggalan hijriah secara umum, yang hitungannya bersifat mendekati saja.

- Hisab hakiki taqribi merupakan data rata-rata waktu ijtimak pada tahun Qamariah. Kedua bentuk ini berdasarkan perhitungan dengan landasan asumsi geosentris, pada hal yang benar adalah heliosentris. Dengan Demikian perhitungan berdasarkan asumsi secara ilmiah tidak benar akan menyimpang cukup jauh dari hasil perhitungan astronomi mutakhir. ${ }^{5}$

${ }^{5}$ B.J.Habibie, Rukyat Dengan Teknologi, (Jakarta: Gema Insani Press, 1994), h.18 Jurnal WARAQAT $\bullet$ Volume II, No. 1, Januari-Juni $2017 \mid 2$ 
Pada umumnya sistem tersebut di atas disadur dari kitab kuning, yang menggunakan data astronomi sebagai hasil penelitian para ahli di masa yang cukup lama, karena berumur ratusan tahun dan menggunakan sistem tabel. Hanya saja keistimewaan dari sistem ini perhitungannya dapat dilakukan dengan sederhana, mudah dan cepat tanpa harus mencari data baru, namun kelemahannya tidak memperoleh hasil yang tepat dan teliti.

Berikutnya dalam menentukan awal shalat secara manual dengan melihat bayang-bayang suatu benda, kelemahannya kadang-kadang sulit dilakukan karena faktor alam. Demikian juga arah kiblat yang manual, dengan melihat matahari terbenam di sebelah Barat. Kelemahannya matahari tidak selalu di bagian Barat terbenam karena lintasan matahari berkisar $23,5^{0} \mathrm{LU}$ sampai $23,5^{0} \mathrm{LS}$. Jadi matahari terbenam selalu berpindah-pindah dari ufuk Barat secara teratur, dimana $23,5^{0}$ LU menuju mendekati arah mata angin ke Barat Laut, sedangkan $23,5^{\circ} \mathrm{LS}$ mendekati arah mata angin ke Barat Daya.

Dengan latarbelakang di atas, sangat penting untuk dikaji atau ditelusuri lebih lanjut, sebagai salah satu alternatif dari pertikaian paham yang terjadi di kalangan ulama, sehingga masyarakat puas dan bisa menerima arus perkembangan sains dan teknologi dewasa ini. Dari gambaran sepintas dalam latar belakang masalah di atas dapat ditegaskan bahwa masalah pokok yang hendak dibahas dalam penelitian ini adalah bagaimanakah penggunaan media elektronika dalam menentukan pelaksanaan waku ibadah menurut pandangan hukum Islam.

Pada satu sisi, tujuan utama penelitian ini adalah untuk menjawab pertanyaan pokok di atas, sedangkan pada sisi lain tujuan dari penelitian ini adalah untuk mengetahui apakah boleh menggunakan media elektronika dalam menentukan pelaksanaan waktu ibadah. Adapun manfaat yang dapat diambil dari penelitian ini adalah untuk mendapat informasi dan data yang diperoleh tentang penggunaan media elektronika dalam menentukan ibadah umat Islam. 


\section{Pembahasan}

Ilmu Falak atau Astronomi adalah suatu ilmu pengetahuan yang mempelajari benda-benda langit berkenaan fisiknya, geraknya, ukurannya dan segala sesuatu yang berhubungan dengannya. ${ }^{1}$

Menurut M. Wardan ilmu falak terbagi dua macam:

1. Ilmu yang dihubung-hubungkan dengan ramalan tentang kejadian-kejadian atau keadaan yang belum terjadi. Pengetahuan ini disebut Astrologi (Ilmu Nudjum).

2. Ilmu yang tidak dihubung-hubungkan dengan ramalan tetapi sekedar untuk mengetahui dan mempelajari letak, gerak, ukuran lingkaran benda-benda langit dengan didasarkan kepada ilmiah, dengan pengetahuan itu dapat menentukan hitungan tahun, bulan demikian pula gerhana. Ilmu yang kedua ini disebut Astronomi (Ilmu Haiah).

Jelaslah bahwa ilmu falak yang dimaksud dalam penentuan pelaksanaan waktu ibadah oleh umat Islam terkait dengan ilmu Astronomi, karena menyangkut pengamatan, penelitian secara ilmiah terhadap benda-benda langit.

Ilmu Hisab modern dalam prakteknya banyak menggunakan ilmu pasti yang kebenarannya sudah tidak diragukan lagi. Ilmu tersebut adalah Spherical Trigonometri (Ilmu Ukur Segi Tiga Bola). Di samping itu Ilmu Hisab modern menggunakan data yang dikontrol oleh observasi setiap saat. Di sisi lain ilmu hisab hanya memberikan hasil perhitungan dalam soal waktu dan posisi saja, seperti dalam bentuk posisi Hilal awal bulan. Ilmu Hisab tidak mengatakan bahwa hilal pada posisi tertentu pasti atau mustahil kelihatan. Kelihatan atau tidaknya tergantung kepada hasil ru'yat pada waktunya.

Ru'yat adalah lafadz bahasa Arab yang berarti "melihat", kata kerjanya $R a$ a. Ra a mempunyai beberapa mashdar, antara lain rukyan dan rukyatan. Rukyan berarti "mimpi", sedangkan rukyatan berarti "melihat dengan mata atau dengan

${ }^{1}$ Badan Hisab dan Rukyat Depag, Almanak Hisab Rukyat, (Jakarta :Proyek Pembinaan Badan Peradilan Agama, 1981), h.14. Lihat K.R. Muhammad Wardan, Kitab Falak dan Hisab, (Yogjakarta: Pandu, th), h.5 
akal atau dengan hati”. Kedua masdar mempunyai isim jamak yang sama, yaitu Ru an. ${ }^{1}$

Ru'yat berarti melihat dengan mata atau melihat dengan akal, akan tetapi ru'yat dalam pembicaraan ini dimaksudkan untuk melihat dengan mata.

Dalam Al-Qur'an tidak ada satupun ayat yang tegas memerintahkan rukyat dalam menetukan awal bulan qamariah. Namun demikian, Al-Qur'an banyak pula mengemukakan tentang gerak dan keadaan benda-benda langit, terutama bulan dan matahari, serta dikaitkan dengan periode bulan Qamariyah.

Di antara ayat-ayat tersebut Surat Yunus ayat 5 yang artinya:

"Dialah yang menjadikan matahari bersinar dan bulan bercahaya, dan ditetapkannya manzilah-manzilah (tempat-tempat) bagi perjalanan bulan itu, supaya kamu mengetahui bilangan tahun danperhitungan (waktu). Allah tidak menciptakan yang demikian itu melainkan dengan haknya. Dia menjelaskan tanda-tanda (kebesaran Nya) kepada orang yang mengetahui".

Kata-kata disambung dengan menunjukkan bahwa bilangan yang dimaksud oleh ayat tersebut adalah tahun Qamariyah (lunar calendar) sebagai rangkaian dari bulan-bulan Qamariyah.

Dalam surat Yasin ayat: 39 disebutkan bahwa Allah menjadikan manzilahmanzilah bulan, sehingga setelah bulan menduduki manzilah terakhir, ia kembali mempunyai bentuk seperti tandan tua (bulan sabit).

Pelaksaanaan rukyat yang dilakukan oleh masyarakat pada tanggal 29 Sya'ban dan 29 Ramadhan mempunyai peran yang sangat menentukan dalam penentuan awal bulan Ramadhan dan Syawal. Walaupun para ulama berlainan pendapat tentang wajibnya pelaksanaan rukyat pada kedua tanggal tersebut namun mereka sepakat bahwa laporan "telah melihat hilal" yang dilakukan oleh saksi yang adil merupakan alat bukti untuk menetapkan awal bulan Ramadhan dan Syawal.

Kemudian pelaksanaan rukyatpun mempunyai peran yang sangat besar dalam melakukan kontrol terhadap suatu hasil perhitungan. Dengan banyaknya sistem dan berbeda-bedanya data serta cara perhitungan yang digunakan, maka

${ }^{1}$ Kamus Al Munjid, (Beirut : Dar al-Masyrik, 1977), Cet. Ke-18, h.243 
sudah barang tentu akan memperoleh hasil yang berbeda-beda pula. Hal ini merupakan kelemahan sistem hisab sendiri secara keseluruhan. Keadaan seperti ini dapat di atasi dengan pengecekan di lapangan dengan melakukan rukyat secara terarah, teliti dan berulang kali sehingga dapat diperoleh suatu kesimpulan sistem mana yang mendekati kebenaran dan dapat dijadikan pegangan.

Dewasa ini hisab waktu shalat telah berkembang menurut metode yang berbeda. Ini dapat diklasifikasikan sebagai berikut; ada yang masih memakai metode tradisional (manual), ada yang lebih maju sedikit dari tradisional (semi manual), dan ada yang memakai kemajuan teknologi modern seperti penggunaan data ephemeris. Sebagai perbandingannya akan dijelaskan di bawah ini :

a. Metode tradisional

Metode ini sama dengan penentuan waktu shalat dengan melihat bayangbayang suatu benda (tanda-tanda) di permukaan bumi yang menunjukkan masuknya waktu. Hal ini dilakukan untuk mengamalkan nash (hadits) yang memberi petunjuk tentang batas-batas waktu shalat tersebut. ${ }^{13}$

Pada pola tradisional ini, bila bayang-bayang tak ada, tanda-tanda tersebut sulit diketahui maka jalan yang ditempuh adalah menjadikan hari kemaren sebagai ukurannya dan dilambatkan sedikit untuk kehati-hatian. Sebagai contoh waktu ashar, bayang-bayang sudah menunjukkan waktu masuk pada pukul 15.50, sementara di hari sesudahnya bayang-bayang tersebut tidak dapat diamati. Maka dijadikanlah jam 15.50 sebagai ukuran lalu dilambatkan sedikit menjadi jam 15.52 .

Kalau diperhatikan lebih lanjut dari jalan penyelesaian ini, ukuran bayangbayang ashar pada pukul 15.50 sama dengan bayang-bayang Ashar di hari sesudahnya. Adapun untuk melambatkan sedikit bukanlah sebagai patokan, namun hanya untuk kehati-hatian saja. Ini menunjukkan peredaran matahari tetap dalam lintasannya, sementara pergerakan matahari relatif tetap (artinya berubah-ubah / berpindah-pindah secara teratur) karena deklinasi (lintasan) matahari berkisar $23,5^{0}$ LU pada tanggal 22 Juni sampai $23,5^{\circ} \mathrm{LS}$ pada tanggal

${ }^{13}$ Ibnu Hajar al 'Asqilani, Bulugul al Maram, (Beirut : Maktabah, t.th), h. 
22 Desember mengakibatkan bayang-bayang berpindah-pindah pula secara teratur. Sebagai akibatnya juga tentu waktu (jamnya) turut berubah pula. ${ }^{14}$

Jadi tidaklah dapat dijadikan pedoman terus bayang-bayang yang satu hari itu ke hari yang lainnya, Oleh karena itu perlu setiap saat (hari) hendaknya memantau bayang-bayang tersebut agar terlepas dari kekeliruan dalam mengamat bayang-bayang

b. Metode semi modern

Metode ini sudah melewati langkah kemajuan dari tradisional. Metode semacam ini mempergunakan sistem tabel, sehingga lebih cepat dan praktis, hanya saja tinggal mengoreksinya sesuai dengan letak suatu negri berdasarkan koordinat negeri (lintang dan bujurnya). Jadwal-jadwal shalat telah tercantum sedemikian rupa dan berlaku untuk sepanjang masa seperti buku Saadoe'ddin Djambek.

Buku Saadoe'ddin Djambek masih dipakai orang dalam menetukan hisab awal waktu shalat. Bukunya menerangkan langkah-langkah dalam penggunaan waktu shalat sebagai berikut :

- Bagian pertama (berupa jadwal shalat)

- Bagian kedua (daftar nama negeri)

- Cara menggunakan pedoman tersebut

- $\quad$ Kedudukan ihtiath

- Jalan hisab ini

Melihat dari jalan hisab dengan cara ini, ada semacam ketetapan yaitu tentang penggunaan deklinasi matahari $(d)$ dan equation of time $(e)$ yang dirujuk dari Almanak Nautika tahun 1996. Sementara deklinasi dan equation of time dari hari ke hari senantiasa selalu berubah menurut peredaran matahari. Itu makanya setiap tahun diterbitkan buku Ephemeris Hisab Dan Rukyat dan buku Almanak Nautika.

${ }^{14}$ Nurmal Nur, Op.cit., h. 30. Lihat Ephemeris, h. 
Menurut penulis penggunaan metode ini masih ada ahli hisab yang memakainya, sebab ;

(1) Cara tersebut lebih cepat, mudah dan praktis digunakan, karena tinggal lagi melihat tabel kemudian melakukan pengoreksian terhadap suatu negeri setempat. Penggunaannya sudah cukup dengan alat kalkulator.

(2) Jadwal-jadwal shalat yang sudah tersusun dalam satu tahun sekarang misalnya, dapat dijadikan pedoman pula untuk tahun besok dan di tahun berikutnya (bisa berlaku sepanjang masa).

(3) Karena sulitnya mendapatkan data lintasan peredaran matahari yang tercantum dalam buku Ephemeris Hisab dan Rukyat dan buku Almanak nautika setiap tahun. Sebab buku-buku itu diperoleh dari London dan diperbanyak oleh orang Indonesia (Depag buku Ephemeris, TNI Angkatan laut buku Almanak Nautika ) kemudian diedarkan pada instansi-instansi tertentu setiap tahun, tidak diperjual-belikan (diperdagangkan). Dengan demikian ada kecendrungan oleh ahli hisab memakai metode tabel tersebut.

(4) Di samping itu juga, hanya metode itulah keahliannya yang bisa dalam menghisab awal waktu shalat. Sebab meskipun memakai rumus-rumus metode ketiga seperti nanti yang akan dijelaskan di bawah ini (yakni memakai rumus-rumusnya dan data Ephemeris) dengan bantuan alat kalkulator sangat melamakan sekali dalam menghisab jadwal waktu shalat dalam satu tahun. Belum lagi waktu kehati-hatian, misalnya terjadi kesalahan baik memakai rumus atau memasukan data, tentu harus diulang kembali dari awalnya. Hal inilah keengganan ahli hisab untuk memakai metode ketiga dengan bantuan kalkulator karena merepotkan sekali dan menghabiskan waktu, yang akhirnya ia memutuskan untuk memakai sistem tabel pegangan Saadoe'ddin djambek yaitu Pedoman Waktu Shalat Sepanjang Masa.

c. Hisab dengan menggunakan teknologi maju

Hisab denga teknologi ini serba cepat, baik dalam memperoleh data ataupun menghisab dengan rumus-rumus tersendiri. Langkah ini dapat dibantu dengan alat pogram bantuan komputer, sedangkan kalkulator 
merupakan semi komputer (artinya sudah cepat dari hitungan biasa tanpa alat dan lebih lambat dari komputer).

Penggunaan rumus-rumusnya dengan memakai data Ephemeris Hisab Rukyat atau Almanak Nautika yang setiap tahunnya dipakai. Adapun bentuk rumusnya sebagai berikut ${ }^{16}$; Untuk daerah WIB

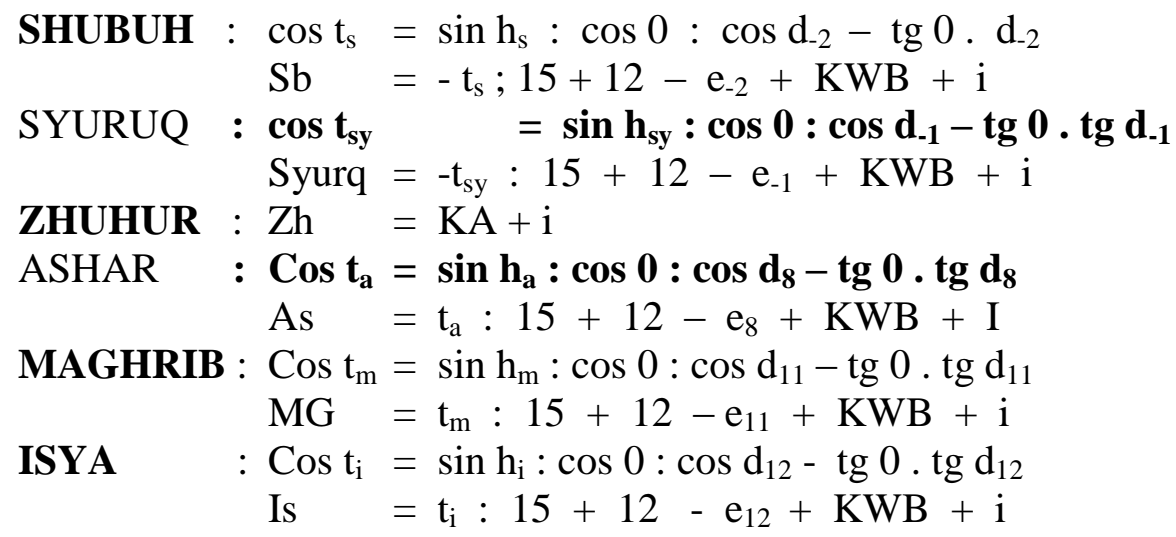

Keterangan :

$$
\begin{aligned}
& \mathrm{t}=\text { sudut waktu matahari } \\
& \mathrm{D}=\text { deklinasi matahari } \\
& \mathrm{E} \quad=\text { equation of time } \\
& \text { KWB }=\text { Koreksi waktu bujur, KWB = (bujur standar-bujur }
\end{aligned}
$$

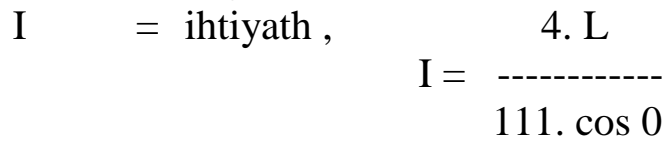

Catatan: Untuk daerah WITA dan WIT sama dengan WIB hanya saja yang berbeda adalah pemakaian deklinasi dan equation of time. Jarak WIB ke WITA ada $15^{\circ}$ bujur negeri $=1$ jam, demikian juga WITA ke WIT ada 1 jam.

${ }^{16}$ Nurmal Nur, Ilmu Falak, (Padang : tp., 1997), h.39-42. Lihat Ephemeris, h.126-432 


\section{Hasil Penelitian dan Kesimpulan}

Memang dari segi nash telah menjelaskan tata cara pelaksanaan waktu ibadah, seperti penentuan awal puasa (1 Ramadhan) dan awal berbuka (1 Syawal).

Hadits telah memberikan jalan awal penentuan puasa yakni rukyat dan istikmal (bila rukyat tidak bisa dilakukan, maka jalan keluarnya menyempurnakan hitungan). Dengan demikian puasa harus dihentikan apabila telah terlihat hilal (ru'yatul hilal), bukan karena adanya hilal (wujud hilal). Artinya sekalipun hilal telah wujud (ada), tetapi jika tidak terukyat maka belum wajib puasa. Rasulullah shallallahu 'alaihi wa sallam. memberi petunjuk agar melakukan istikmal bila terjadi mendung. ${ }^{14}$

Mengenai dalil tersebut, pandangan ulama (golongan rukyat) menyatakan bahwa lafad syahida dalam ayat menunjukkan arti hadhara yang di dalamnya terkandung dhamir untuk orang yang bermukim yang menyaksikan hilal (bukan musafir dan bukan orang sakit) yang dengan demikian orang yang bermukim tersebut wajib puasa. ${ }^{15}$

Sedangkan lafad ra'a yang terdapat dalam hadits itu hanya boleh diartikan dengan melihat dengan mata kepala meskipun kata itu bisa diartikan secara luas. Alasannya adalah bahwa kelanjutan hadits tersebut menyebutkan kata-kata ghumma yang berarti mendung, sedangkan akal fikiran atau pengetahuan tidak dapat dihalangi oleh mendung. Seandainya lafaz ghumma tersebut diartikan secara majazi (yang terhalang itu akal fikiran) maka pengertiannya tidak tepat, sebab bagaimana seseorang bisa menghitung dengan benar dalam keadaan fikirannya terhalang. Begitu pula lafaz faqdurulah diartikan para ahli rukyat secara majazi yaitu fakmilu iddata tsalatsin (menyempurnakan bilangan bulan itu menjadi 30 hari). Pengambilan makna majazi dari makna hakiki didasarkan pada suatu qarenah, yaitu hadits yang diriwayatkan oleh al-Bukhari. Jika faqdurulah diartikan dengan faqrudu

\footnotetext{
${ }^{14}$ Lihat CD Hadist Muslim, menjelaskan hadist marfu' mutashil dan dari segi kuantitas ahad serta kualitas shahih dalam bab Shiyam no. 1798

${ }^{15}$ Al-Qurthubi, Al Jaami' li Ahkam al-Qur'an,, (Beirut : Dar al Kutub al 'Alamiyah, t.th), h.200
} 
bi hasabil manazil, maka bagaimana mengartikan hadits tersebut, tentu saja terdapat kejanggalan.Selanjutnya hisab telah dilarang oleh syari'at

Sementara ahli hisab lafad syahida tersebut di atas menjadi maf'ul bukan zharaf zaman yang berarti melihat (menyaksikan) hilal, dan demikian juga lafad raa pada hadits Ibnu Umar. Adapun menafsirkan faqdurulah dalam hadits tentang dengan makna faqduru bi hisabil manazil (hitungan dengan manzilah-manzilah bulan), yakni yakni apabila hilal tertutup awan, maka hisablah berdasarkan perjalanan bulan dan matahari. ${ }^{9}$ Kemudian tertujunya hadits dengan rukyat karena pada waktu itu orang tidak pandai menulis dan menghitung. Adapun yang pandai menulis dan menghitung hanya sedikit sekali dan dikhawatirkan sekali kalau membebankan umat. Tapi sekarang orang sudah banyak yang bisa menulis dan menghitung, maka tidak perlu lagi rukyat. Sebab (illat) hukum telah hilang (berubah ) mengakibatkan hukum berubah pula. Sebagaimana kaidah ushul fiqh yang artinya:

Hukum itu beredar bersamaan adanya illat dan tidaknya illat ${ }^{10}$

Jadi dalam penafsiran makna faqdurulah (pengkadaran) inilah kontroversi hisab-rukyat dimulai. Ahli rukyat cendrung menerjemahkan nya dengan menggenapkan hitungan bulan menjadi 30 hari. Ahli hisab menafsirkannya dengan penetapan melalui hisab atau perhitungan menurut kaidah-kaidah ilmu astronomi.

Demikianlah nash telah menjelaskan secara tekstual untuk mengawali dan mengakhiri puasa hanya dengan rukyat dan istikmal, meskipun tingkat keakurasiannya dipermasalahkan. Tuntunan tersebut sesuai dengan prinsip yang dianut Syari'ah dalam menilai sah dan tidaknya suatu ibadah adalah merupakan persoalan zhan. Lain halnya dalam persoalan mu'amalah yang baru dianggap sah jika sesuai dengan kenyataan.

Andaikan sahnya ibadah berdasarkan atas kenyataan, maka akan timbul berbagai kesulitan. Sebagai contoh tentang masalah sahnya shalat. Shalat dianggap sah jika suci badannya, pakaiannya, dan tempat shalatnya dari najis.

\footnotetext{
${ }^{9}$ Ibnu Rusyd, Bidayatul Mujtahid, (Beirut: Dar al Fikr, t.th), Juz 1, h.. 207

${ }^{10}$ Kawai fiqh
} 
Apabila tingkat kesucian tersebut harus sesuai dengan kenyataan yang sesungguhnya dan tidak cukup atas dasar zhan. Maka setiap orang akan shalat harus diperiksa terlebih dahulu badannya, pakaiannya, dan tempat shalatnya dengan alat mutakhir yang dapat membuktikan secara pasti dan nyata bahwa ketiga hal tersebut sudah bersih dari najis.

Walaupun demikian perlu juga dilihat bagaimana kondisi hadits itu diturunkan. Yakni daerah tempat diturunkannya hadits terdahulu (Arab Saudi) daerah yang bergurun pasir, sangat kering dan datar, langit umumnya cerah, sehingga di sana rukyat sangat mudah dilakukan, bahkan dengan mata telanjang.

Sementara itu ada tempat-tempat yang di mana rukyat sulit dilakukan, yaitu daerah yang lembab dan banyak berawan, atau di tempat-tempat yang setiap hari turun hujan. Demikian pula di tempat-tempat sekitar kutub, yang disana satu "hari” bisa berlangsung berbulan-bulan, begitu pula saat malamnya.

Disinilah persoalannya, oleh sebab itu jika karena berbagai sebab praktis rukyat tidak mungkin dilakukan, maka ia boleh ditinggalkan. Jika hasil rukyat diragukan, lebih baik menggunakan cara yang lebih meyakinkan. Inilah pengertian luas dan kontekstual dari "kadarkanlah kepadanya" (faqduruu lahu) pada hadits Bukhari-Muslim

Jadi, dari pemahaman terhadap hadits ini, sebenarnya pengembangan teknologi rukyat yang tembus awan tidak perlu terlalu dipaksakan karena dalam kondisi ini rukyat menjadi tidak wajib. Bukankah Allah ta'ala tidak pernah menyulitkan hamba-Nya dalam menjalankan perintah-Nya.

Terlepas dari perbedaan pendapat ulama tentang istilah rukyat dan kadar, yang perlu diperhatikan adalah penentuan awal Ramadhan dan Syawal dilakukan berdasarkan hasil rukyat kecuali jika langit mendung. Berdasarkan hal itu rukyat hanya dilakukan jika langit cerah dan tak ada yang menghalangi pandangan. Oleh karena itu dalam penentuan awal bulan, tetap harus dilakukan rukyat untuk membuktikan hisab. Jika ternyata rukyat tidak berhasil maka wajib mengamalkan hadits Rasul shallallahu 'alaihi wa sallam yakni menggenapkan bilangan bulan sedang berlangsung 30 hari. 
Oleh karena itu, walaupun seandainya telah ditemukan teknologi untuk merukyat bulan dalam keadaan mendung, namun sepanjang Syari'ah Islam belum dapat menerimanya, maka upaya teknologi rukyat ini ditangguhkan. Karena sikap ini sudah mengalihkan esensi rukyat itu sendiri, di samping itu Teknologi Rukyat Mendung jauh lebih mahal dari Teknologi Rukyat Cerah .

Dalam rangka menanggulangi persoalan sulitnya rukyat karena kondisi alam, maka timbullah teknologi rukyat. Pada dasarnya ulama tidak keberatan dengan menggunakan teknologi untuk pelaksanaan rukyat. Sebelum teknologi untuk pelaksanaan rukyat dikembangkan, ICMI Orsat Puspitek dan ICMI Orsat Pasar Jumat telah menyenggarakan diskusi panel "Teknologi Rukyat Objektif Untuk Penentuan Awal dan Akhir Ramadhan” pada tanggal 3 September 1993 di kawasan Puspitek Serpong.

Umumnya semua pihak memberi kesempatan kepada kalangan teknolog untuk mewujudkan gagasannya. Lewat Khatib 'Am Syuriah PBNU, K.H. Ma'rif Amin, secara resmi NU mendukung penggunaan alat ini, bahkan telah mengeluarkan fatwa bahwa jika langit tertutup awan dan tekologi yang mampu merekam hilal maka PBNU akan menerima keabsahannya dari Syari'ah Islam.

Menurut hemat penulis, terhadap fatwa NU yang berani menyatakan "mengabsahkan teknologi meskipun hilal tertutup awan" adalah karena teknologi benar-benar menyatakan (menampilkan) apa adanya. Artinya mengungkapkan secara fakta bukan mengada-ngada. Dan hilal itu benar terlihat adanya. Jadi , yang jelas hilal itu benar-benar nampak dan ia berada di atas ufuk (horizon).

Memang prinsipnya ulama tidak keberatan atas ikut sertanya iptek dalam proses penentuan awal dan akhir Ramadhan, sepanjang tidak mengabaikan ketentuan Syari'at. Penggunaan alat untuk pengamatan hilal masih dapat diterima sepanjang kemampuan alat tersebut tidak terlalu jauh selisihnya dengan mata bugil. Sebagaimana halnya fungsi hisab (yaitu membantu terlaksananya rukyat), demikian pulalah fungsi alat harus ditempatkan sebagai pemandu dan pembantu rukyat dengan mata bugil.

Namun, ketika hisab ingin menjadi penentu timbul perselisihan dikalangan ulama sendiri. Sebagaimana yang dijelaskan Ma'ruf Amin dalam 
tulisannya Rukyat Untuk Penentuan Awal dan Akhir Ramadhan Menurut Pandangan Syar'I dan Sorotan Iptek menyatakan bahwa : ${ }^{11}$

Malikiyah, Hanafiah dan Hanabilah tidak dapat menerima kehadiran hisab secara mutlak, baik untuk perorangan maupun untuk umum.

Imam Subki, Abbadi dan Qalyubi mewakili arus pendapat yang mendukung tuntutan hisab tersebut. Imam Subki menyatakan jika ada satu atau dua orang bersaksi melihat bulan sedang menurut hisab tidak mungkin, maka kesaksiaan tersebut ditolak (I'anatutthalibin, $2: 216$ )

Pendapat Imam Subki dan kawan-kawannya ditolak oleh mayoritas ulama yang dimotori oleh Imam Ramli dan Al-Khatib Syarbaini. Menurut ar-Ramli yang harus diterima adalah kesaksian rukyat, karena hisab telah diabaikan oleh syari'at. ${ }^{12}$

Menurut penulis, Malikiyah, Hanafiyah dan Hanabilah tidak mau menerima hisab karena hisab yang berkembang saat itu, hisab astrolog. Demikian juga hisab telah diabaikan oleh syara', sebab merupakan rekaan saja. Sedangkan pendapat Subki menerima hisab karena itu yang lebih meyakinkan (qath'i) ketimbang merukyat merupakan dugaan / sangkaan orang (dhan). Oleh karena itu bila bertentangan antara hisab dan rukyat maka hisblah yang dimenangkan.

Berdasarkan hal itu hisab dan rukyat masih pada tahap yang sederhana, karena masih ada pertentangan antara hisab dan rukyat. Untuk sekarang ini tidaklah demikian, sains berkembang mengakibatkan berkembangnya hisab dan rukyat. Sekarang hisab dan rukyat dapat menyatu (saling keterkaitan), sebab sains tersebut dapat menghitungkan hasil yang akurat dan dapat menampakkan rukyat yang lebih jelas dan nyata. Oleh karena itu hisab dan rukyat tidak saling bertentangan, tapi saling mendukung. Yang cocok dipakai oleh dunia sekarang adalah ide yang dikembangkan oleh Ibnu Hajar yakni mengambil jalan tengah. Maksudnya bukan meniadakan salah satu di antara keduanya seperti hisab saja atau rukyat saja, tapi memakai -menggabungkan- keduanya (yaitu hisab dan rukyat).

11 Ma'ruf Amin, Rukyat Untuk Penentuan Awal dan Akhir Ramadhan Menurut Pandangan Syar'i dan sorotan IPTEK (Jakarta : Al Hikmah, 1991), h.71

${ }^{12}$ Ahmad bin Hajar, Nihayatul al-Muhtaj, (t.th, Dar al-Kutub al ilmiah : tt ), juz.III, h.351 
Mengingat perkembangan sekarang yakni sains bertambah maju, lebih akurat ketimbang di masa silam. Sebab sains yang berkembang sekarang didukung oleh penelitian-penelitian yang lebih akurat, menggunakan data-data baru yang lebih teliti, lebih mengungkapkan fakta yang ada.

Kalau diperhatikan hisab rukyat dahulu berbeda sekali dengan hisab rukyat sekarang. Hisab yang disangkal orang dulu adalah hisab yang digunakan oleh ahli bintang, berupa rekaan-rekaan saja. Rukyat dulu, orang melakukannya dengan cara melihat dengan mata telanjang, karena itulah yang dipahami tentang rukyat diwaktu itu. Namun sekarang dunia berbalik yakni ketika hisab itu digunakan astrolog, sekarang beralih kepada astronom. Begitu juga rukyat dengan melihat tanpa alat bantu, sekarang sudah menggunakan alat bantu yakni teropong hilal (theodolit).

Adapun rukyat bil fi'li dengan menggunakan alat ada beberapa pendapat antara lain Pendapat yang lebih tegas dikemukakan oleh Al Muthi'I. Ia menyatakan $^{12}$ :

'Rukyat bil fi'li dengan menggunakan alat tetap dapat diterima karena yang terlihat melalui alat tersebut adalah hilal itu sendiri (ainul hilal) bukan yang lain. Fungsi alat hanya untuk membantu penglihatan dalam melihat yang jauh atau sesuatu yang kecil"'.

Adapun yang dikemukakan oleh guru kami adalah tidak boleh berpegang kepada rukyat di air atau dibelakang kaca, maksudnya adalah melihat dengan posisi terbalik. Dan cara melihat seperti itu, tidak dapat diterima. Sedangkan melihat dengan alat pada hakekatnya sama dengan melihat kuman dengan menggunakan mikroskop.

Dari berbagai komentar tersebut andaikata Ibnu Hajar hidup di masa ini, tentu kaca yang dimaksud bukanlah termasuk di situ teropong hilal. Sebab teropong hilal di waktu itu belum lagi ditemukan, karena teropong membantu penglihatan dari yang jauh tampak kecil bisa terlihat dekat dan besar menurut ukurannya. Memang hilal itu ada di atas ufuk, tapi karena jauh akan terlihat kecil. Kalaulah seandainya orang pergi mendekatinya di atas ufuk (horizon) tersebut akan terlihat hilal itu besar menurut semestinya.

${ }^{12}$ Op. Cit., h.72 
Ternyata kemampuan IPTEK dewasa ini telah memberikan sarana dalam memudahkan, melancarkan pelaksanaan waktu ibadah. Berbarengan dengan itu ajaran Islam menganjurkan umatnya berfikir yang dinyatakan dalam beberapa ayat. Perintah berfikir tersebut supaya merenungkan (membaca) kejadian dan fenomena alam. Hal ini tidak lain Islam tidak menolak hasil ilmu pengetahuan.

Kehadiran ilmu pengetahuan semakin berkembang menurut kemajuan zamannya. Oleh karena itu, dengan perkembangan tersebut suatu ilmu tidak bersifat mutlak (bersifat tentatif). Artinya objek penelitian terdahulu bisa tumbang oleh objek penelitian yang baru, karena dilengkapi data-data baru yang lebih teliti dan akurat.

Penggunaan teropong untuk merukyat sama dengan penggunaan kaca mata waktu membaca. Pada waktu tes penglihatan, dokter menyuruh melihat abjat dari dekat, ternyata nampak abjat tersebut. Namun ketika abjat itu sudah jauh, kelihatannya lebih kecil atau kabur tak terlihat. Oleh karena itu dokter memberikan kaca mata yang sesuai untuk penglihatan tersebut. Jadi kaca itu membantu penglihatan benda yang jauh.

Memang puasa itu dilakukan dengan rukyat adalah merupakan suatu ibadah, di mana sifat ibadah tersebut bersifat taukifi sebagaimana kaidah usul "Asal dalam ibadah bersifat tauqifi"

Tapi kalau bicara tentang teknik rukyat, bukan lagi menyangkut persoalan ibadah, namun sudah menjurus ke persoalan mu'amalah. Dimana dalam muamalah hukum asalnya boleh, sebagaimana kaidah ushul fiqih

Hal ini sama dengan mikropon untuk azan dan pesawat terbang untuk berangkat naik haji. Dulu azan di manara yang tinggi agar terdengar sama orang, tapi sekarang cukup dengan mikropon yang menyambung suara azan. Ketika mu'azin azan di mesjid dengan suara yang tidak sampai keluar mesjid, tapi dengan bantuan mikropon suara tersebut bisa sampai keluar mesjid, bahkan seluruh penduduk kampung dapat mendengar sebagai pertanda seruan shalat.

Terlihatlah dari contoh ini bukan azannya yang dirubah, tapi suaranya dibantu agar lebih keras dan terdengar oleh orang banyak. Demikianlah halnya dengan hilal, bukan rukyatnya yang dirubah, tapi penglihatan yang jauh itu 
dibantu agar benar-benar nampak. Sebab berdasarkan hukum alam yakni sesuatu bila terlalu jauh akan kelihatan kecil atau tak tampak. Pada hal ia (hilal) ada di atas ufuk itu sendiri.

Demikian juga dengan pesawat terbang, dulu orang pergi naik haji dengan berlayar berbulan-bulan lamanya. Sekarang dengan kemajuan IPTEK (pesawat terbang) cuma hanya beberapa jam saja. Pesawat ini telah membantu dalam mempermudah untuk naik haji dibandingkan teropong juga mempermudah dalam melakukan rukyat sebagaimana mestinya.

Perumpamaan tersebut tidak lain adalah dengan menggunakan metode qiyas. Yakni theodolit tersebut terdapat illat yang sama yaitu sama-sama melihat wujud hilal, bahkan dengan theodolit akan memepermudah dalam melancarkan waktu ibadah. Bentuk qiyas ini dalam ilmu ushul fiqh disebut qiyas aulawi yang disepakati oleh para ulama.

Dalam hal ini, antara dua pandangan (hisab dan rukyat) tidak perlu dipertentangkan, karena keduanya dapat dipertemukan, saling mengisi dan memperkuat. Mengingat kondisi di mana ilmu pengetahuan telah begitu canggih seperti dewasa ini, di mana dengan peralatan yang canggih itu jauh-jauh hari tanggal atau bulan sudah bisa diketahui letak dan posisinya. Lebih dari itu kesemuanya itu adalah hasil ijtihad yang statusnya hanya zhanni.

\section{Kesimpulan}

Perkembangan teknologi dapat merubah tehnik hisab dan rukyat sepanjang tidak keluar dari prinsip Syari'at. Oleh karena itu media elektronika merupakan buah (hasil) dari IPTEK dapat menjawab persoalan waktu ibadah secara tepat, cepat dan akurat. Dengan demikian ia sebagai alat bantu dalam melancarkan pelaksanaan ibadah, sebab mengandung kemaslahatan yang nyata.

Menyinggung hal ini, secara hukum Islam persoalan tehnik merupakan persoalan dunia. Oleh karena itu, persoalan tersebut diserahkan kepada manusia menurut kemampuan perkembangan zamannya. Di samping itu ajaran Islam berlaku untuk sepanjang zaman. Artinya cara (tehnik) orang dahulu tidak bisa lagi dipakai di masa dewasa ini, maka cara tersebut dapat dikembangkan lebih luas. 
Oleh karena itu, nash yang menyatakan (melihat dengan mata kepala) dapat dikembangkan menjadi melihat dengan alat bantu. Jadi hukum menggunakan media elektronika dalam pelaksanaan waktu ibadah adalah boleh dan sah.

\section{Pustaka Acuan}

Abdurrahman Taj, Shiam Ramadhan, penerjemah Yusuf, judul asli "Shaumu Ramadhan", (Solo: Pustaka Mantiq, 1987), Cet.ke-1

Anas, Malik bin, Muwaththa', (Beirut: Dar al Kutub al 'Alamiyah, t.th), Juz I

A.Katsir, Matahari dan Bulan dengan Hisab, (Surabaya: Bina Ilmu, 1997)

Ali, M.Suyuthi, Ilmu Falak, (Jakarta: RajaGrafindo Persada, 1997), Cet.ke-1

Al-Baihaqi, Sunan Kubra, (Beirut: Dar al Fikr, t.th), Juz IV

B.J Habibie, Rukyat dan Teknologi, (Jakarta: Gema Insani Press, 1994)

Benua, Pantja, Ilmu Bumi, Pasti dan Alam, (Payakumbuh: Pustaka Eleonora, t.th, Cet.ke-2)

Departemen Agama, Pedoman Perhitungan Awal Bulan Qamariah (Jakarta: Proyek Pembinaan Administrasi Hukum dan Peradilan Agama, 1983)

Djambek, Saadoe'ddin, Hisab Awal Bulan, (Jakarta: Tintamas, 1976), Cet. Ke-1

Fak.Teknik Sipil \& Perencanaan Institut Teknologi Bandung, Almanak Matahari dan Bintang, (Bandung : tp., 1985)

Hajar, Ahmad bin, Nihayatul al Muhtaj, (tt : Dar al Kutub al Ilmiyah, t.th), Juz III

Ibnu Rusyd, Bidayatul Mujtahid, (Bairut : Dar al Fikr, t.th), Juz I

Ibrahim, Abdullah, "Masalah Rukyat dan Hisab dari Perspektif Islam”, Makalah, [tidak diterbitkan]

Ibnu Hajar al 'Asqalani, Fathul al Baari, (Bairut : Dar al Kitab al 'alamiyah, t.th), Juz IV

Ibnu 'Abidin, Al-Radd al-Muhtar 'ala al-Durr al-Mukhtar, (Beirut : Dar al Kutub al 'Alamiyah, t.th), Juz II

Al Jaziri, Abdur al Rahman, Kitab al Fiqh 'Ala al Mazhabu al Arba' (Beirut : Dar al Fikr, t.th), Juz I 
M.S. Torun, Pokok-pokok Ilmu Falak (Semarang : banteng Timur, 1953)

Muhajjir, Noeng, Metode Penelitian Kualitatif, (Jogyakarta : Rake Sarasin, 1989)

Nur, Nurmal, Ilmu Falak, (Padang : tp., 1997)

Nadwi, Ali Ahmad, Qawaid Fiqhiyah, (Damaskus : Dar Kalam, 1994), Cet.ke-3

Purwanto dan D.N. Dawanas, Peran Astronomi dalam penentuan Awal Bulan Hijriah, (Jakarta : Al Hikmah, 1991)

Qardawi, Yusuf, Fiqih Puasa, penerjemah Ma'ruf Abdul Jalil, dkk., judul asli "Fiqh Ash-Shiam" (Surakarta : Era Intermedia, 2000, Cet.ke-2)

Al-Qurafi, Al Furuq, (Beirut : 'Alam al Kutub, t.th), Juz I

Al-Qurthubi, Al Jami' li Ahkam al Qur'an, (Beirut : Dar al Kitab al 'Alamiyah, t.th), Juz I

Rahman, Abdul, Ilmu Falak, (Jakarta : Liberty, 1983)

Syarifuddin, Amir, Ushul Faiqh, (Jakarta : Logos, 1997)

Al Suyuthi, Jalaluddin, Al Asybah wa Al Nazhair fi Al Furu' (Beirut : Dar AlFikri, 1995)

Thaha, Ahmadie, Astronomi dalam Islam, (Surabaya : Bina Ilmu, 1983, Cet.ke-1)

Wardan, Muhammad, Hisab U’rfi dan Hisab Hakiki, (Jogjakarta : Siaran, 1957)

Wahid, Basit, "Mengapa Muhammadiyah Menetapkan 1 Syawal 1418 Jatuh Pada tgl 29 Januari 1998", Makalah, [tidak diterbitkan]

Widiana, Wahyu, "Dasar-dasar Ilmu Falak dalam Menentukan Awal Bulan Qamariah", Makalah, [tidak diterbitkan]

Zarqani, Manahilul al Irfan, (Beirut: Dar al Kitabal 'Alamiyah, t.th), Juz I

ZA.Mawardi, Gerhana Matahari Menurut Pandangan Islam, (Surabaya: Sinar Wijaya, 1982)

Zainal, Baharuddin, "Ke Arah Meningkatkan Keupayaan Merukyat”, Makalah, [tidak diterbitkan] 